\title{
Acute necrotizing encephalopathy as a H1N1 complication: A rare case
}

\author{
H1N1 komplikasyonu olarak ortaya çıkan akut \\ nekrotizan ensefalopati: Nadir bir olgu
}

\author{
Dilek Gökharmann ${ }^{1}$, Havva Akmaz Ünliü ${ }^{2}$, Sonay Aydın ${ }^{1}$, Cihat Tek ${ }^{1}$, Pinar Nercis Kosar ${ }^{1}$
}

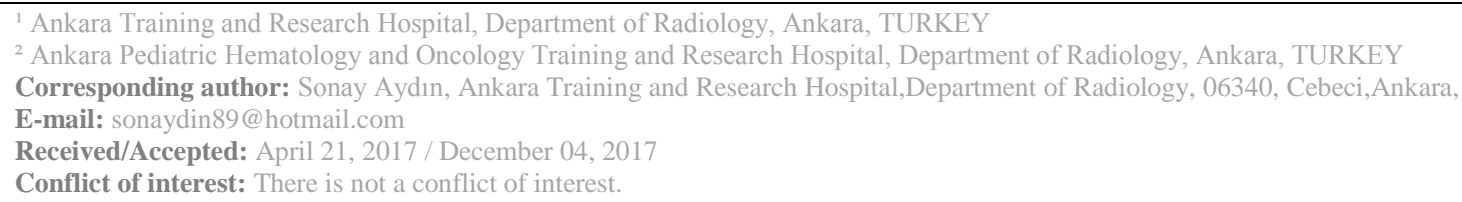

\section{SUMMARY}

\begin{abstract}
Acute necrotizing encephalopathy of childhood (ANEC) is a rare type of encephalopathy seen generally in previously healthy children or infants of East Asian population. The pathology generally considered to be triggered by infectious diseases, mainly by viral agents. In this case report a previously healthy, 2-year -old, male children diagnosed as ANEC, occuring secondarily to H1N1 infection is presented. On MR images hyperintensity is present at bilateral thalamus and brainstem on T2WI and FLAIR. On gradient echo sequences, hemorrage is also present at bilateral thalamic region. ANEC does not have a specific symptomor typical neurological sign. It is important to remember that the typical lesions are generally seen in the gray matter of bilateral thalami. It is reported that administration of steroids within first 24 hours just after ANEC diagnosis was related to a better prognosis in patients without brain stem involvement. Early diagnosis mostly depends on knowing the imaging characteristics of ANEC and being aware of this rare entitiy.
\end{abstract}

Keywords: ANEC, H1N1, MRI, Pediatric

\section{ÖZET}

Çocukluk çağının akut nekrotizan ensefalopatisi, sıklıkla viral enfeksiyonların tetiklediği nadir görülen bir ensefalopati formudur. Bu hastalık özellikle bilateral talamusta yerleșen beyaz cevher lezyonları ile kendini göstermektedir. Beyin sapı da sıklıkla tutulan lokalizasyonlar arasındadır. Hastalığa özgü bir nörolojik semptom ya da laboratuar bulgusu ne yazık ki tanımlanmamıştır. En yaygın anormallikler artmış serum aminotransferaz aktivitesi ve beyin omurilik sıvısındaki artmış protein düzeyidir. Hastalığın etyopatogenezi tam olarak bilinememektedir. Yaygın kabul gören spesifik bir tedavi metodu da yoktur. Prognoz genellikle kötüdür, literatürde \% 70 e varan mortalite oranları belirtilmektedir. Tanı genellikle klinik şüphe ve takiben elde edilen tipik görüntüleme bulguları birleştirilerek konulur. Bu olgu sunumunda daha önceden tamamıyla sağlıklı olan iki yaşındaki erkek çocukta, H1N1 infeksiyonunu takiben gelişen akut nekrotizan ensefalopati vakasının görüntüleme bulguları sunulmaktadır. Bu nadir antitenin erken tanısında en önemli nokta tipik görüntüleme bulgularının bilinmesi ve bu nadir antitenin ayırıcı tanıda akılda bulundurulmasıdır.

Anahtar sözcükler: ANEK, H1N1, MRG, Pediyatrik

\section{INTRODUCTION}

Acute necrotizing encephalopathy of childhood (ANEC) is a rare type of encephalopathy seen generally in previously healthy children or infants of East Asian population, especially Japan and Taiwan. However, an increasing number of cases have been reported in countries, too. The pathology generally considered to be triggered by infectious diseases, mainly by viral agents. Some of the most common pathogens to cause ANEC can be summarised as; mycoplasma,influenza virus (typically H3N2), herpes simplex virus, and human herpes virus-6. Patients with ANEC unfortunately 
do not have typical symptoms or neurological signs. Clinical features do not vary between Asian and non-Asian patients ${ }^{1,2}$. In this case we will present a rare ANEC case occuring secondarily H1N1 infection with its MRI findings.

\section{CASE REPORT}

A previously healthy, 2-year -old, male children was applied to pediatric emergency department with complaints of high fever, caugh and recurrent (3 times in a day)seizure. On first examination, he was febrile, and hypertonic. Babinski reflex was positive. Complete blood count, PT, PTT, and urine analysis deteceted no abnormal findings.
Analysis of cerebrospinal fluid is also performed; cell count was normal, there was only slightly elevated protein levels. Phenobarbital was prescribed to settle the seizures. The clinical diagnosis tended to be acute encephalitis. MRI examination was performed. On MR images hyperintensity is present at bilateral thalamus and brainstem on T2WI and FLAIR. On gradient echo sequences, hemorrage is also present at bilateral thalamic region (Figure 1,2,3). Thus final diagnosis of ANEC was confirmed on the basis of both clinical and radiological findings. The presence of H1N1 influenza virus infection was confirmed by reverse transcription-PCR analysis of nasopharyngeal secretions.
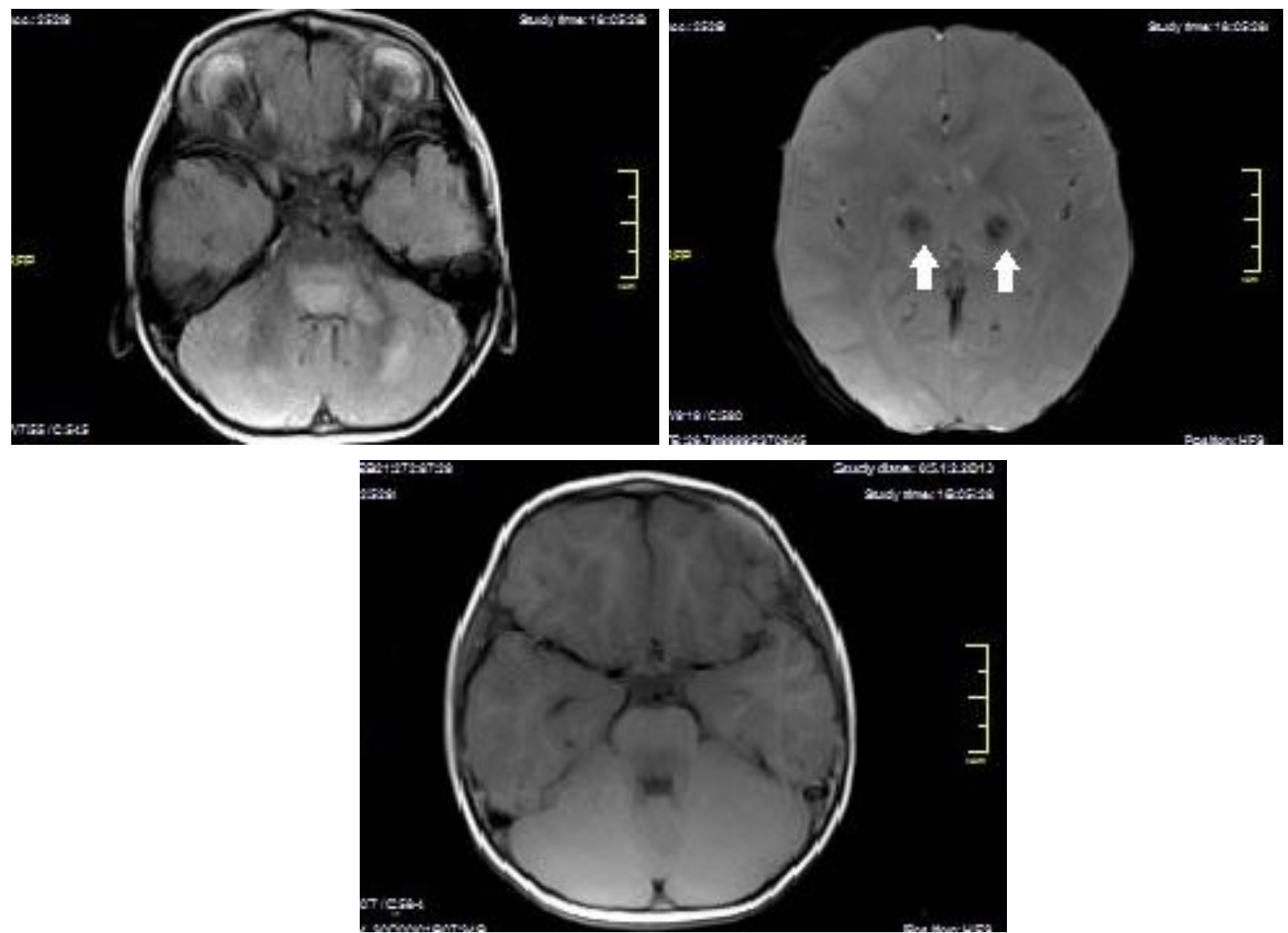

Figure 1: The thalamic lesions are seen hypointense on T1WI (a), hyperintense on T2WI and FLAIR (b,c). 

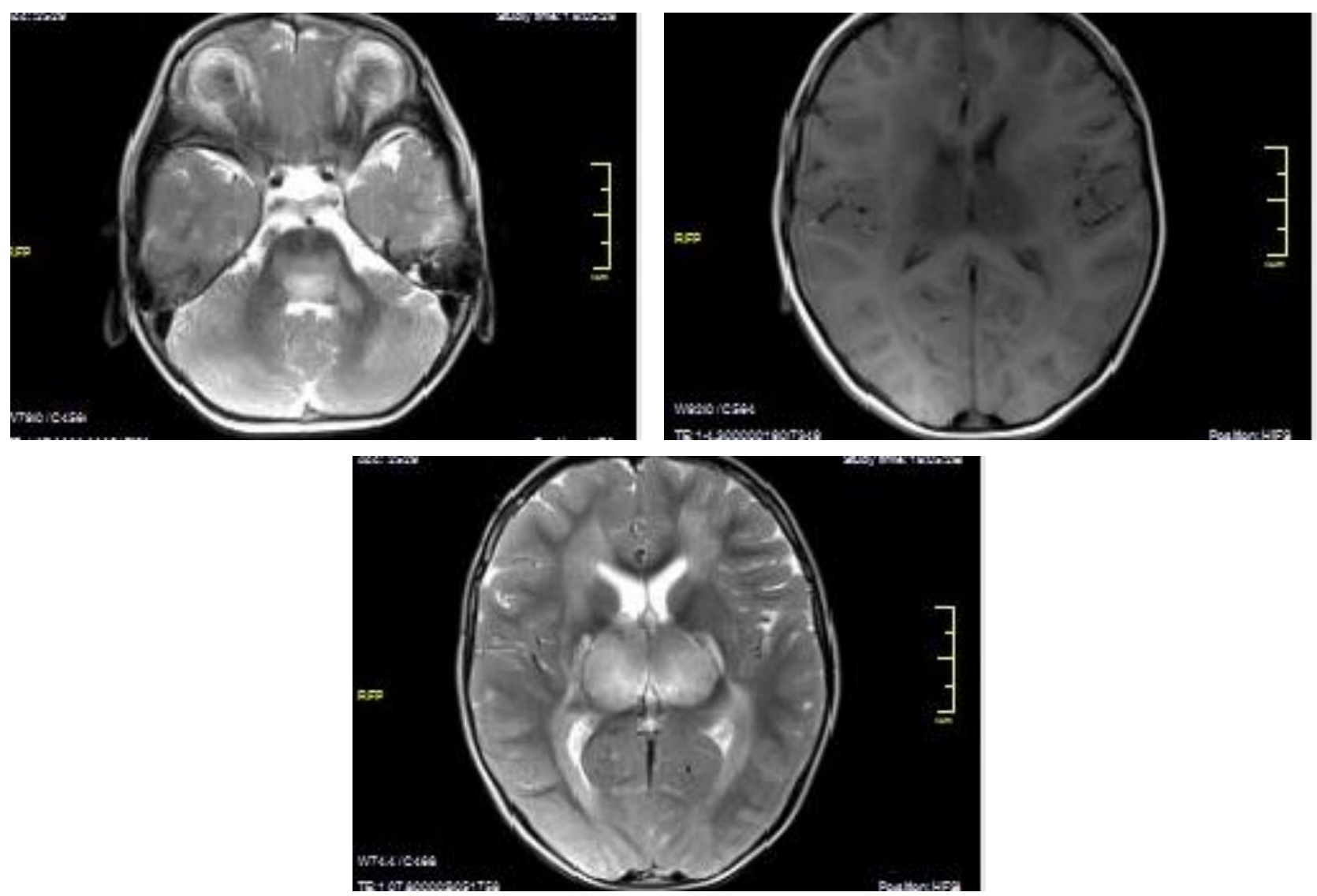

Figure 2: The brainstem lesions are seen hypointense on T1WI (a), hyperintense on T2WI and FLAIR (b,c).

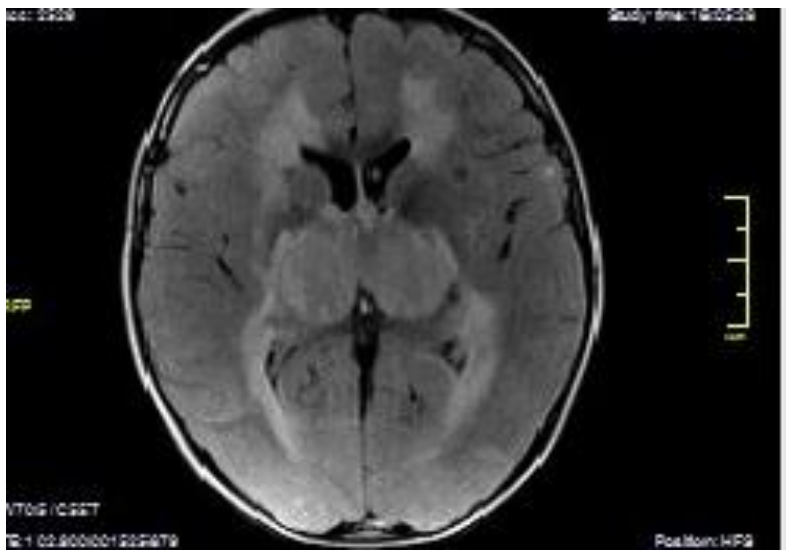

Figure 3: The hypointensities belong to hemorrage are seen on gradient echo sequence at bilateral thalamus (arrows).

Diazepam, levodopa, and trihexifenidilo were used to treat seizures. Oseltamivir was given for 10 days to treat H1N1. Although seizures and fever gradually declined, unfortunately he developed

\section{DISCUSSION}

ANEC is a rare disease, generally seen in the children who have been previously healthy. It is more commonly seen in the East Asia, however sporadic cases were found all over the world ${ }^{3}$. ANEC is described primarily as a clinicoradiologic mental and physical sequelae. Supportive care including physiotherapy, and outpatient supports was planned after discharging from hospital.

disorder with unknown etiology. The etiology and the pathogenesis is stil unclear.Generally, the pathology develops after a viral viral infection. Influenza $A$ and influenza B, parainfluenza, varicella, human herpesvirus 6 and herpesvirus 7 (HHV-6 and HHV-7), enterovirus, novel reovirus train (MRV2Tou05), rotavirus, herpes simplex 
virus, rubella, coxsackie A9, and measles are some of the most common pathogens to trigger ANEC ${ }^{2}$, 4 .

ANEC does not have a specific symptomor typical neurological sign. Prodromal symptoms, including fever, signs of upper respiratory tract infections and gastroenteritis, and erythema, generally shows up due to different viral infections. Other than these,patients with ANEC can present with SIRS like shock, multiple organ failure ,and disseminated intravascular coagulation. While the disease processes, brain dysfunctions may present as seizures, disturbance of consciousness, and focal neurological deficits. Abnormalities of liver function without hyperammonemia, hypoglycemia, or lactic acidosis can be a usefull sign for differential diagnosis. The prognosis of ANEC is very poor, mortality rates can rise up to $70 \%{ }^{2,5}$.

It is important to remember that the typical lesions are generally seen in the gray matter of bilateral thalami.Brainstem involvement can be seen,too. On CT images, the lesion areas appear hypointens. Intracranial hemorrage and cavitations, which are poor prognostic factors, can be also detected on CT. The lesions appear hypointens on T1W1, hyperintens on T2WI and FLAIR. Gradient echo and the susceptibility weighted imaging are quite helpful in deteceting small petechial hemorrage. Postcontrast enhancement can be present ${ }^{2}$.

Differential diagnosis includes Rey syndrome, Leigh disease (hyperammonemia, hypoglycemia, metabolic acidosis), ADEM (pleocytosis in CSF examinarion, generally unilateral involvement) and Japanese encephalitis (common involvement of cortex $)^{4}$.

There has been no widely accepted therapiy for ANEC so far. Intensive care, symptomatic treatment and antiviral therapy, and immunomodulatory agents are some of the tested methods. Intravenous glucocorticoids, immunoglobulin, and plasmapheresis are thought to be effective in ANEC theraphy. Among these, intravenous glucocorticoids (e.g. methylprednisolone and dexamethasone) were the most mentioned and studied ones. It is reported that administration of steroids within first 24 hours just after ANEC diagnosis was related to a better prognosis in patients without brain stem involvement. Unfortunately, there has been no standardized and widely accepted theraphy scheme for ANEC yet ${ }^{2,5}$.

As stated in the literature and similarly in our case report, ANEC occuring secondarily to H1N1 infection, has no specific or sensitive finding compared with other ANEC cases. It is widely emphasized and recommended in the literature that, knowing ANEC entitiy and remembering the possibility of encountering it after a H1N1 infection is the primary key to diagnosis ${ }^{4,5}$.

ANEC is a rare clinicoradiologic disorder. It can be seen following almost every type of viral infection.Early diagnosis mostly depends on knowing the imaging characteristics of ANEC and being aware of this rare entitiy.

\section{REFERENCES}

1. Salehiomran MR, Nooreddini H, Baghdadi F. Acute necrotizing encephalopathy of childhood; a case report. Iran J Child Neurol. 2013;7(2):51-4.

2. Wu X, Wu W, Pan W, Wu L, Liu K, Zhang HL. Acute necrotizing encephalopathy: an underrecognized clinicoradiologic disorder. Mediators Inflamm. 2015;2015:792578.

3. Yoganathan S, Sudhakar SV, James EJ, Thomas MM. Acute necrotising encephalopathy in a child with H1N1 influenza infection: a clinicoradiological diagnosis and follow-up. BMJ Case Rep. 2016;2016.

4. Yadav S, Das CJ, Kumar V, Lodha R. Acute necrotizing encephalopathy. Indian $\mathrm{J}$ Pediatr. 2010;77(3):307-9.

5. Khan MR, Maheshwari PK, Ali SA, Anwarul H. Acute necrotizing encephalopathy of childhood: a fatal complication of swine flu. J Coll Physicians Surg Pak. 2011;21(2):119-20. 